\title{
Elżbieta Skrzypek
}

Uniwersytet Marii Curie-Skłodowskiej w Lublinie

e-mail: elzbieta.skrzypek@umcs.lublin.pl

\section{RAPORTOWANIE KAPITAEU \\ INTELEKTUALNEGO ORGANIZACJI}

\section{INTELLECTUAL CAPITAL \\ REPORTING OF AN ORGANIZATION}

DOI: $10.15611 /$ pn.2017.481.07

JEL Classification: C81

Streszczenie: Celem artykułu jest wskazanie istoty, znaczenia, narzędzi do raportowania o kapitale intelektualnym organizacji. Obiektem oceny są organizacje funkcjonujące w warunkach nowej gospodarki. Metoda badawcza opiera się na krytycznej analizie dostępnej literatury przedmiotu. W artykule wskazano, że kapitał intelektualny stanowi najsilniejszy atut w tworzeniu wartości firmy i jej przewagi konkurencyjnej. Podkreślono, że tworzy on ponadprzeciętną wartość dla przedsiębiorstwa, dlatego konieczne jest mierzenie i komunikowanie jego wartości interesariuszom. Odniesiono się do wybranych metod pomiaru kapitału intelektualnego, wskazując jego wady i zalety. Przedstawiono istotę, potrzebę i zalety raportowania o kapitale intelektualnym. Odniesiono się do dyrektywy UE dotyczącej ujawniania informacji niefinansowych.

Słowa kluczowe: kapitał intelektualny, raportowanie, wartość organizacji, metody pomiaru, wycena.

Summary: This article aims to portray the essence, the meaning and the tools necessary to enable intellectual capital reporting based on the available scientific literature. The subjects of intellectual capital evaluation are organizations functioning in the reality of the new economy. The article finds that intellectual capital is a key asset that adds the most value to the company and helps it build its competitive advantage over rivals. Therefore, it is necessary to evaluate intellectual capital and communicate it to stakeholders. Furthermore, this article covers various methods of intellectual capital valuation. It covers the pros and cons of intellectual capital reporting. Finally, it touches upon EU non-financial reporting directive.

Keywords: intellectual capital, reporting, intellectual capital valuation, intellectual capital valuation methods, pricing. 


\section{Wstęp}

Kapitał intelektualny w warunkach nowej gospodarki jest zasobem niematerialnym o charakterze strategicznym. Wpływa on na kształtowanie wartości organizacji. Rosnący udział kapitału intelektualnego w strukturze zasobów wymusza poszukiwanie sposobów jego wyceny, mierzenia i raportowania. Od informacji dostarczanych przez przedsiębiorstwa oczekuje się wiarygodności i przejrzystości oraz odpowiedniej jakości. Kapitał intelektualny kształtuje wartości, które znajdują odzwierciedlenie w sprawozdaniach finansowych. Metody pomiaru kapitału intelektualnego rozwijają się, nie wypracowano jednak jednego wspólnego standardu raportowania kapitału intelektualnego firm. $Z$ analizy rynku wynika, że dane finansowe są niewystarczające, pojawia się potrzeba raportowania danych pozafinansowych. Raport i proces raportowania w obszarze kapitału intelektualnego ma na celu dostarczanie interesariuszom pełnej informacji o kapitale intelektualnym. Pomiar kapitału intelektualnego w warunkach zmian, ryzyka i niepewności jest koniecznością, istnieje wiele przesłanek przemawiających za pomiarem kapitału intelektualnego. Wycena kapitału intelektualnego nie znajduje odzwierciedlenia w tradycyjnych sprawozdaniach finansowych. Parlament Europejski w 2014 roku wydał Dyrektywę 2014/95/ UE odnoszącą się do ujawnienia informacji niefinansowych. Stanowi ona odpowiedź na dylematy związane z potrzebą i koniecznością ujawniania informacji niejawnych.

\section{Kapital intelektualny jako zasób strategiczny organizacji}

Kapitał intelektualny to bardzo ważny zasób współczesnego przedsiębiorstwa. Współczesne przedsiębiorstwa są elastyczne, wytwarzają inteligentne produkty i usługi, posiadają zaangażowanych klientów uczestniczących $\mathrm{w}$ projektowaniu i produkcji, współpracują z różnymi podmiotami, takimi jak dostawcy, dystrybutorzy, partnerzy strategiczni połączeni w łańcuch wspólnego przeznaczenia, a ich podstawą jest zarówno wiedza jawna, jak i ukryta. Dynamiczny wzrost wartości uzależniony jest od kapitału intelektualnego, jaki posiada jednostka, i umiejętności jego wykorzystania oraz zarządzania nim [Edvinsson, Malone 2001, s. 15]. Kapitał intelektualny jest niepieniężny i dotyczy cech jakościowych, skoncentrowany jest na przyszłości, wypełnia lukę między wartością księgową i rynkową. Jego jakość wpisana jest w jakość produktów i usług oraz ma duży wpływ na rozwój i przewagę konkurencyjną na rynku. Kapitał intelektualny to zasób strategiczny. J. Barney wyróżnił następujące cechy aktywów strategicznych: cenne, rzadkie, trudne do imitacji, dobrze zorganizowane [Barney 1991, s. 99-120]. Kapitał intelektualny cechuje otwartość, unikalność, wartość, pozyskiwanie wiedzy, różnorodność występowania, twórczość, innowacyjność, zmienność, rzadkość, modulacyjność, ciągły rozwój, trwałość i akomodacyjność [Szara, Pierścionek 2007, s. 255]. Kapitał intelektualny umożliwia tworzenie nowych produktów, marek, reputacji firmy, wzrost efektywności wykorzystania zasobów, wykorzystanie szans płynących z otoczenia, budowanie 
dobrych relacji wewnętrznych i zewnętrznych, własny rozwój oraz możliwości prowadzenia na szerszą skalę prac $\mathrm{B}+\mathrm{R}$.

Prekursorami w dziedzinie budowania przewagi konkurencyjnej za pomocą kapitału intelektualnego były szwedzkie przedsiębiorstwa, między innymi WM Data, która w 1989 roku wydała pionierski aneks do swojego raportu finansowego w całości poświęcony kapitałowi intelektualnemu, oraz Skandia AFS jako pierwsze przedsiębiorstwo, które powołało stanowisko dyrektora do spraw kapitału intelektualnego [Rogowski 2006, s. 64]. W raporcie Konrada udowodniono, że w nowej gospodarce znaczenie wskaźników finansowych maleje i coraz większą rolę pełnią wskaźniki pozafinansowe oraz wiedza, doświadczenie, kontakty kluczowych pracowników [Kunasz 2005, s. 156].

Kapitał intelektualny to najsilniejszy atut w tworzeniu wartości firmy i jej przewagi konkurencyjnej na rynku. Brak odzwierciedlenia w sprawozdawczości finansowej aktywów intelektualnych powoduje dysproporcje w dostępie do informacji pomiędzy kierownictwem firmy a inwestorami. Rozwiązanie problemu może nastąpić poprzez stworzenie dodatkowego sprawozdania o kapitale intelektualnym albo poprzez wprowadzenie do rachunkowości zarządczej mierników niefinansowych, które umożliwią pełniejsze odwzorowanie realizowanej przez przedsiębiorstwo strategii. W 1964 roku Hermanson stwierdził, że tradycyjny bilans nie ukazuje pełnego obrazu przedsiębiorstwa, bo nie obejmuje kapitału ludzkiego, a nakłady na pozyskanie i rozwój ludzi w organizacji to inwestycje, a nie koszty, ponieważ korzyści mogą przynieść w przyszłości [Dudycz 2005, s. 215]. Próbę ujęcia zasobów ludzkich w bilansie, która się nie udała, podjęli w 1968 roku Brummet, Flamholtz i Pyle. W latach 90. XX wieku opublikowano kilka koncepcji raportowania, skierowanych na potrzeby interesariuszy wewnętrznych, np. Skandia Nawigator czy Monitor Aktywów Niematerialnych. Za pioniera w dziedzinie pomiaru kapitału intelektualnego uznaje się firmę Skandia, której model uwzględnił dwie formy kapitału intelektualnego: kapitał ludzki i kapitał strukturalny. Skandia w 1991 roku jako pierwsza wprowadziła do struktury organizacyjnej stanowisko dyrektora ds. kapitału intelektualnego, określając jednocześnie misje dla kapitału intelektualnego [Sopińska 2005, s. 45]. Równocześnie w USA powstała zbilansowana karta dokonań oraz model autorstwa Kaplana i Nortona, który przyczynił się do spopularyzowania koncepcji kapitału intelektualnego.

Kapitał intelektualny jest trudny do imitowania, dlatego tworzy ponadprzeciętną wartość dla przedsiębiorstwa, zatem w pełni uzasadnione i potrzebne jest mierzenie i komunikowanie jego wartości. Liderzy biznesu i analitycy finansowi są zdania, że praktyki rachunkowości i sprawozdawczości finansowej nie nadążają za zmianami w świecie biznesu. Według Walkmana sprawozdania finansowe nie mierzą i nie pokazują najważniejszych budulców biznesu, do których należy zaliczyć kapitał ludzki, organizacyjny i kapitał klientów [Fijałkowska 2016a, s. 1]. Raportowanie prezentuje informację i wiedzę o firmie i jej aktywach. Interesariusze wymagają jasności i całościowego ujęcia schematu raportowania oraz informacji zawartych w raportach, które powinny być obiektywne. Raportowanie odnoszące się do kapitału intelektualnego 
wymaga ujęcia przyszłościowego i korzysta z informacji o charakterze jakościowym, które są trudne do wyceny pieniężnej. Kapitał intelektualny obejmuje oprócz elementów wewnętrznych elementy zewnętrzne, w tym relacje z klientami.

S. Kasiewicz wraz z zespołem wskazał na warunki, które prowadzą do odpowiedniej jakości informacji zawartych w raportach [Kasiewicz, Rogowski, Kicińska (red.) 2006, s. 117]:

- przekazywana informacja powinna dotyczyć zdolności firmy do tworzenia wartości, zdolność ta zależy od procesów, wiedzy i doświadczenia pracowników i zarządu, raport powinien ujmować te działania i skutki, wpływ na wzrost wartości organizacji,

- model raportowania powinien być oparty na relacjach pomiędzy elementami kapitału ludzkiego, natężeniu powiązań i bezpośrednich efektach,

- model raportowania powinien ukazywać pełny przepływ informacji dla interesariuszy zewnętrznych,

- raport musi zawierać informacje dotyczące stabilności aktywów niematerialnych i czynników powodujących zmiany w wartości lub rozmiarach kapitału intelektualnego.

Kapitał intelektualny kształtuje wartości urzeczywistniane w sprawozdaniach finansowych, które są bardzo istotne dla wszystkich interesariuszy [Skrzypek 2016, s. 39-80]. Pomiar kapitału intelektualnego ma bardzo duże znaczenie dla audytorów badających sprawozdania finansowe. W ocenie sprawozdania finansowego coraz większą wagę przywiązuje się do takich nośników wartości, jak: wiedza, umiejętności menedżerskie, kreatywność, relacje z klientami, innowacyjność, własność intelektualna, niematerialne aktywa strukturalne. Wartości te trzeba zidentyfikować, prawidłowo oszacować i dokonać ich ewaluacji. Pomiar kapitału intelektualnego budzi coraz większe zainteresowanie wśród badaczy. Skuteczny pomiar wymaga całościowego ujęcia. Rozwój nowych metod pomiarowych ma na celu wzrost jakości decyzji podejmowanych przez kierownictwo w oparciu o te metody. Metody wyceny kapitału intelektualnego $\mathrm{w}$ aspekcie jakościowym stanowią uzupełnienie metod statystycznych, są ukierunkowane na przyszłość przedsiębiorstwa. Pomiar kapitału intelektualnego powinien uwzględnić mierniki ilościowe i jakościowe. L. Edvinsson porównuje ten pomiar do opisu pogody: nie można opisać pogody, nie posługując się liczbami, lecz oprócz tego potrzebny jest opis słowny [Edvinsson 2002].

W przeważającej większości udostępniane publicznie informacje są danymi finansowymi. Jak wynika jednak z analizy rynku, dane te nie są wystarczające do oceny wartości waloru i często wśród inwestorów pojawia się zapotrzebowanie na raportowanie danych pozafinansowych (kapitału intelektualnego). Koncentrowanie się tylko na danych finansowych daje niepełny obraz przedsiębiorstwa. Ponadto prowadzi do asymetrii informacji i ogranicza możliwości podejmowania trafnych decyzji przez interesariuszy. Działalności gospodarczej towarzyszy niepewność, ryzyko i zmiana, dlatego użytkownicy informacji biznesowych oczekują dostępu do informacji niefinansowych. Powinna cechować je bardzo wysoka jakość, wysoki poziom rzetelności 
oraz transparentności. Dlatego Parlament Europejski 22 XI 2014 roku wydał nową Dyrektywę 2014/95/UE, która dotyczy ujawnienia informacji niefinansowych.

\section{Pomiar kapitału intelektualnego - pilna potrzeba i konieczność}

Pomiar kapitału intelektualnego to poważne wyzwanie, przed jakim stoją współcześnie społeczeństwa i przedsiębiorstwa. Z uwagi na wielowymiarowość tego kapitału i różne potrzeby stawiane przed raportem o kapitale intelektualnym przez poszczególnych interesariuszy, rozwijane są różne metody oceny kapitału intelektualnego. Brakuje jednak jednego wspólnego standardu raportowania kapitału intelektualnego firm. Można uznać, że jest to ważny powód niechęci organizacji do publikowania raportów o kapitale intelektualnym. Raport i sam proces raportowania w obszarze kapitału intelektualnego ma na celu dostarczenie inwestorom pełnej informacji o kapitale intelektualnym, jednocześnie przedstawione w nim dane nie powinny zawierać informacji poufnych, aby nie zaszkodzić spółce w kontekście utraty swojej konkurencyjności. Zarazem należy wskazać koszty, które ponosi przedsiębiorstwo w związku z publikowaniem raportów o kapitale intelektualnym, a są to: możliwość zmniejszenia przewagi konkurencyjnej z powodu ujawnienia informacji o źródłach przewagi konkurencyjnej, możliwość osłabienia siły przetargowej wobec interesariuszy, koszty ewentualnych procesów sądowych, wynikających z ujawnienia dodatkowych informacji o aktywach niematerialnych. Wśród czynników, które mają wpływ na pozycję konkurencyjną organizacji, należy wskazać na rodzaj ujawnionej informacji, poziom jej szczegółowości oraz czas ujawnienia.

Zarządzanie relacjami inwestorskimi poprzez raportowanie o kapitale intelektualnym staje się coraz bardziej istotne w związku z powstaniem luki wartości wynikającej z faktu, iż o wycenie spółki decyduje już nie majątek rzeczowy i finansowy, a niewidoczny kapitał intelektualny, którego wycena nie jest podawana w tradycyjnych sprawozdaniach finansowych. Raportowanie o kapitale intelektualnym powinno pomóc interesariuszom (akcjonariuszom, klientom, pracownikom etc.) w zrozumieniu, co wpływa na wartość spółki w perspektywie krótko- i długookresowej.

W literaturze wyróżniono dwie koncepcje pomiaru kapitału intelektualnego:

- konieczne jest wyodrębnienie poszczególnych składników kapitału intelektualnego i poddanie ich analizie,

- kapitał intelektualny powinien być mierzony na poziomie całego przedsiębiorstwa bez wyodrębniania oddzielnych jego komponentów, jest to podejście holistyczne. W oparciu o międzynarodowe badania zidentyfikowano ważne motywy, dla których menedżerowie powinni mierzyć kapitał intelektualny [Urbanek 2008, s. 84]:

- uzyskanie podstawy do wyceny przedsiębiorstwa, zorientowane na aktywa,

- stymulowanie koncentracji kierownictwa firmy na najważniejszych czynnikach, zorientowane na działanie,

- uzasadnienie inwestycji w działania związane z zarządzaniem wiedzą, zorientowane na korzyści, 
- poprawa informacji dostarczanych akcjonariuszom, wspomaganie inwestycji,

- zwiększona ilość informacji mogących wspomóc proces podejmowania decyzji,

- pomoc $\mathrm{w}$ zarządzaniu zasobami ludzkimi, pomoc w zarządzaniu relacjami z klientami.

Wśród motywów pomiaru kapitału intelektualnego można zatem wskazać na poprawę wewnętrznego zarządzania przedsiębiorstwem, poprawę jakości raportowania na zewnątrz oraz potrzeby transakcyjne.

Metody pomiaru kapitału intelektualnego podzielono na: kosztowe, rynkowe, dochodowe, oparte na opcjach realnych [Lipka 2007, s. 20]. Celem pomiaru kapitału intelektualnego jest konstruowanie ogólnej strategii organizacji, ocena stopnia, a także sposobu realizacji strategii, wykorzystywanie otrzymanych wyników w systemie motywacyjnym. Pomiar kapitału intelektualnego wymaga określenia wskaźników oraz określenia ich wzajemnych powiązań i relacji, a także dostrzeżenia sposobu, w jaki oddziałują one na funkcjonowanie organizacji [Sopińska 2010, s. 116-120]. Wycena kapitału intelektualnego to określenie jego wartości, opiera się ona na sformalizowanych metodach szacunku. Wśród często stosowanych metod wskazuje się na [Kasiewicz, Rogowski, Kicińska (red.) 2006, s. 60-63]:

- MV/BV (market-to-book value), wskaźnik wartości rynkowej do wartości księgowej,

- wskaźnik q-Tobina (laureata Nagrody Nobla), w miejsce wartości księgowej zastosowano koszty odtworzenia aktywów materialnych,

- CIV (calculated intangible value), metoda oparta na siedmiostopniowej kalkulacji, jej wynikiem jest premia intelektualna,

- KCE (knowledge capital earning), oparta na aktywach materialnych i finansowych i dodanego do nich współczynnika aktywów niematerialnych,

- VAIC (value added intellectual coefficient), współczynnik intelektualnej wartości dodanej, umożliwia oszacowanie efektywności kreowania wartości dodanej, zaczerpniętej z aktywów materialnych i niematerialnych,

- EVA (economic value added), ekonomiczna wartość dodana, metoda zakłada związek z wartością rynkową przedsiębiorstwa, według niej kapitał intelektualny jest wykorzystywany, gdy jego zwrot przewyższa jego koszt.

Za najbardziej kompleksową typologię metod pomiaru kapitału intelektualnego uznawany jest podział zaproponowany przez Karla-Erika Sveiby'ego. Biorąc pod uwagę grupy pomiaru wyróżnione przez Davida H. Luthy'ego, który podzielił metody na metody pomiaru poszczególnych składników kapitału intelektualnego i metody pomiaru kapitału intelektualnego za pomocą przekształceń finansowych [Luthy 2001], dołączył podział metod na dokonujące i niedokonujące wyceny kapitału intelektualnego, zaliczone do czerech grup metod pomiaru [Sveiby 2001]:

- metody oparte na kapitalizacji rynkowej (MCM - Market Capitalization Methods), obliczanie różnicy pomiędzy wartością rynkową a wartością księgową przedsiębiorstwa,

- metody oparte na zwrocie na aktywach (ROA - Return on Assetes Methods), 
- metody bezpośredniego pomiaru kapitału intelektualnego (DIC - Direct Intellectual Capital Methods),

- metody kart punktowych (SC - Scorecards Methods), umożliwiają identyfikację i pomiar składników aktywów niematerialnych za pomocą wskaźników niepieniężnych.

Wyróżniono metody ilościowe i jakościowe oceny kapitału. Jest wiele metod i wiele klasyfikacji, co oznacza niewypracowanie standardów w tym zakresie. Metody pomiaru stale się rozwijają, poszukuje się nowych rozwiązań oraz możliwości usunięcia pewnych wad, które te metody posiadają, a są to [Dominiak, Mercik, Szymańska 2012, s. 683-693]:

- brak dostępności danych do metody z zewnątrz organizacji,

- wykorzystywanie w metodzie jedynie danych finansowych,

- nieuwzględnianie w metodzie wszystkich, bądź niektórych podstawowych elementów kapitału intelektualnego,

- brak syntetycznej wyceny łącznej wielkości kapitału intelektualnego,

- nieuwzględnianie w wycenie kapitału intelektualnego wagi jego elementów składowych.

Biorąc pod uwagę wskazane wady metod pomiaru kapitału intelektualnego, grupa autorów podjęła próbę opracowania metody pomiaru, przygotowując wskaźniki i metody pomiaru w odniesieniu do kadry kierowniczej, pracowników, innowacji, procesów, klientów, sieci wzajemnych powiązań, strategii rozwoju oraz otoczenia biznesowego [Dominiak, Mercik, Szymańska 2012, s. 689]. W oparciu o autorską metodykę pomiaru kapitału intelektualnego oraz doświadczenie audytorskie został opracowany zintegrowany raport, obejmujący zakresem dane finansowe i niefinansowe przedsiębiorstwa. Raport ten ma zastosowanie wewnętrzne, jak i zewnętrzne. Wśród głównych informacji pojawiających się w raportach można wymienić takie obszary, jak: strategia i polityka kadrowa, konkretne programy oraz cele zarządzania zasobami ludzkimi i ich efekty, warunki pracy, zdrowia i bezpieczeństwa pracowników, zasady i poziom wynagrodzenia pracowników oraz systemy motywacyjne, zasady rekrutacji, wielkość zatrudnienia, poziom absencji pracowników, wiek, wykształcenie, pochodzenie etnicznego, podejmowane przez spółkę inicjatywy mające na celu podniesienie kwalifikacji pracowników, satysfakcja pracowników, organizacja wewnętrzna i komunikacja.

M. Mroziewski wskazuje na następujące powody pomiaru kapitału intelektualnego [Mroziewski 2008, s. 50]:

- możliwość uzyskania przewagi konkurencyjnej przez wzrost reakcji na potrzeby klientów,

- wpływ inwestycji w ludzi na poprawę rentowności przedsiębiorstwa,

- lepsza ocena wartości przedsiębiorstwa,

- wpływ na wzrost przyszłej wartości przedsiębiorstwa,

- kontrola operacyjna, by uświadomić sobie wartość ludzi, know-how,

- konieczność podejmowania decyzji dotyczących między innymi kompetencji pracowników, 
- poprawa jakości zarządzania w przedsiębiorstwie,

- doskonalenie systemu informowania interesariuszy.

Według N. Bontisa i J. Fitzenza wykorzystanie metod wartościowania kapitału ludzkiego oraz intelektualnego organizacji umożliwia przewidywanie przyszłości firmy. Jego zadaniem jest przewidywanie efektywności tych kapitałów oraz wskazanie niezbędnych działań w przedsiębiorstwie celem przygotowania do przyszłych działań [Bontis, Fitzenz 2002, s. 213-247].

\section{Raportowanie o kapitale intelektualnym}

Raport o kapitale intelektualnym to zestawienie danych liczbowych i opisowych, umożliwia on przedstawienie sytuacji majątkowej i finansowej oraz pozycji konkurencyjnej, umożliwia komunikację z grupami osób i podmiotów zainteresowanych funkcjonowaniem organizacji. Pozwala na lepsze poznanie przedsiębiorstwa, a także wpływa na kreowanie opinii i postaw interesariuszy. Może przyczynić się do wzrostu znaczenia i wiarygodności firmy. Raportowanie kapitału intelektualnego staje się praktyką w krajach rozwiniętych i nabiera coraz większego znaczenia dla spółek giełdowych, dlatego że powstała dyrektywa Parlamentu Europejskiego i Rady Unii Europejskiej nr 2014/95/UE z 22 listopada 2014 roku, która obliguje do umieszczania danych pozafinansowych w rocznych sprawozdaniach finansowych. Dane pozafinansowe stanowią ważny czynnik cenotwórczy. Jednocześnie identyfikacja i wycena to trudny i pracochłonny proces, ponadto brakuje jednolitych standardów, klasyfikacji wskaźników, mierników i danych porównawczych w poszczególnych branżach.

Dotychczas rozpowszechniły się dwie kategorie raportowania:

- narracyjne sprawozdania i niefinansowe raporty, które zawierają różne typy czynników wpływających na wynik organizacji,

- szczegółowe raporty dotyczące aktywów niematerialnych (intelektualnych).

Odnosząc się do raportowania o kapitale intelektualnym organizacji, należy wskazać na korzyści wynikające z raportowania o kapitale intelektualnym, które obejmują [Kasiewicz, Rogowski, Kicińska (red.) 2006, s. 185]:

- poprawę jakości i wiarygodności informacji,

- wzrost wiarygodności spółki i jej zarządu, poprawa relacji inwestorskich,

- wzrost zainteresowania i przychylności analityków giełdowych i inwestorów,

- zmniejszenie zmienności kursów akcji,

- wzrost liczby inwestorów długoterminowych,

- obniżenie średniego kursu kapitału,

- rozszerzenie możliwości dostępu do bardziej płynnych rynków, charakteryzujących się mniejszą zmiennością cen,

- możliwość korygowania niewłaściwych wycen i zwiększenie wartości i płynności akcji,

- uniknięcie interwencji organów regulujących funkcjonowanie rynku, 
- obniżenie liczby procesów sądowych związanych z podaniem nieprawdziwych danych,

- wzrost prawdopodobieństwa podejmowania efektywnych decyzji inwestycyjnych.

Ponadto należy wskazać na możliwości zmniejszenia niepewności przeszłości przedsiębiorstwa, wzrost efektywności podejmowanych inwestycji oraz łatwiejsze określenie wartości przedsiębiorstwa [Fijałkowska 2016a, s. 2].

Ważnym elementem kapitału intelektualnego jest kapitał ludzki. Raportowanie o kapitale ludzkim ma wiele zalet, w tym sprawienia, że obecnie zatrudnieni pracownicy czują się zmotywowani i docenieni, potencjalni pracownicy mogą dowiedzieć się o warunkach panujących w firmie, co może zachęcić ich do ubiegania się o pracę w niej [Cuganesan, Petty 2010, s. 81].

W warunkach GOW udział zasobów niematerialnych w strukturze zasobów przekracza $80 \%$, zasoby te muszą być wyceniane i uwzględniane w sprawozdawczości finansowej. Nasila się krytyka systemu rachunkowości, który nie uwzględnia aktywów niematerialnych, a także informacji niefinansowych. Wśród powodów ujawniania informacji niefinansowych i niefinansowych miar dokonań w raportowaniu biznesowym należy wskazać na następujące fakty [Fijałkowska 2016b, s. 117]:

- analitycy finansowi biorą pod uwagę miary niefinansowe przy podejmowaniu decyzji i odnoszą się do nich w swoich raportach i rekomendacjach,

- niefinansowe miary dokonań są użyteczne, bo jednocześnie odzwierciedlają i wpływają na wartość przedsiębiorstwa,

- niefinansowe miary dokonań dają możliwość powiązania działań menedżerów z finansowymi rezultatami i przyszłymi antycypowanymi wynikami przedsiębiorstwa,

- niefinansowe miary dokonań mają wpływ na wartość przedsiębiorstwa,

- niefinansowe miary dokonań są pozytywnie skorelowane z dokładnością prognoz finansowych analityków,

- wartość informacyjna miar finansowych jest zwiększona poprzez odniesienie ich do miar niefinansowych.

\section{Dyrektywa 2014/95/UE - ujawnianie informacji niefinansowych}

Dyrektywa 2014/95/UE zmieniająca dyrektywę 2013/34/UE w odniesieniu do ujawniania informacji niefinansowych i informacji dotyczących różnorodności przez niektóre duże spółki oraz grupy została opublikowana w Dzienniku Urzędowym UE 15 listopada 2014 roku. Kraje członkowskie miały czas na jej wdrożenie do 6 grudnia 2016 roku. Zapisy Dyrektywy wchodzą w życie z dniem 1 stycznia 2017 roku. W Dyrektywie ma miejsce rozszerzenie zakresu informacji niefinansowych. Zgodnie z nią duże jednostki zainteresowania publicznego ujawniać będą w sprawozdaniu z działalności minimum istotnych informacji dotyczących: 
- kwestii środowiskowych,

- kwestii pracowniczych,

- kwestii społecznych,

- poszanowania praw człowieka,

- przeciwdziałania korupcji i łapownictwu (sprawozdawczość w zakresie CSR),

- ujawniania polityki prowadzonej w danym zakresie, jej rezultatów oraz ryzyk i zarządzania ryzykiem w kwestiach niefinansowych.

Duża jednostka zainteresowania publicznego to taka, która spełnia łącznie następujące kryteria: średnioroczne zatrudnienie powyżej 500 osób, suma bilansowa powyżej $20 \mathrm{mln}$ EUR lub obroty powyżej $40 \mathrm{mln}$ EUR. Ministerstwo Finansów stwierdziło, że jednostkami traktowanymi jako jednostki zainteresowania publicznego na potrzeby ustawy o rachunkowości będą co najmniej spółki giełdowe, banki, instytucje ubezpieczeniowe [Ministerstwo Finansów 2016].

Zgodnie z Dyrektywą raportowanie może odbywać się według wybranych przez spółki zasad własnych, krajowych, unijnych lub międzynarodowych. Kraje UE mogą zezwolić na ujawnianie informacji przez spółki w formie odrębnego raportu zamiast oświadczenia na temat informacji niefinansowych $\mathrm{w}$ ramach sprawozdania $\mathrm{z}$ działalności.

Według Guzińskiej-Błońskiej znaczna część polskich przedsiębiorstw nie ma doświadczenia w raportowaniu CSR [Guzińska-Błońska 2016]. Według szacunków ponad $80 \%$ ze 118 dużych spółek giełdowych nie przygotowuje takich raportów. Obowiązek sporządzania takich raportów dotyczyć będzie około 250-300 podmiotów. Dziś raporty społeczne publikuje około 40 podmiotów. Według Guzińskiej-Błońskiej czas potrzebny na przygotowanie takiego pierwszego raportu w oparciu o doświadczenia światowe to praca prowadzona przez około pół roku przez około 50 osób, efektem tej pracy jest określenie około stu wskaźników. Według szacunków Ministerstwa Finansów koszt takiego przedsięwzięcia to około 100 tys. zł, a przy zleceniu firmie zewnętrznej nawet ponad 300 tys. zł.

\section{Zakończenie}

W globalnej gospodarce znaczącym źródłem tworzenia wartości jest kapitał intelektualny. Jego pomiar umożliwia ocenę osiąganych postępów, zanim ujawnione one zostaną w tradycyjnym systemie sprawozdawczości finansowej. Kapitał intelektualny wpływa na wzrost wartości rynkowej przedsiębiorstwa. Badanie i ocena kapitału intelektualnego powinny być prowadzone we wszystkich sektorach. W ocenie należy uwzględniać specyfikę branży spółki, stosowany model biznesowy oraz uwarunkowania działalności. Nad koniecznością zmian w tradycyjnej sprawozdawczości biznesowej dyskusje prowadzone są od wielu lat. Proces raportowania w obszarze kapitału intelektualnego ma na celu dostarczenie inwestorom pełnej informacji o kapitale intelektualnym. Zarządzanie relacjami inwestorskimi poprzez raportowanie o kapitale intelektualnym staje się istotne w związku z powstaniem luki wartości 
wynikającej z faktu, iż o wycenie spółki decyduje w coraz większym zakresie kapitał intelektualny. Raportowanie o kapitale intelektualnym powinno umożliwić interesariuszom zrozumienie, co wpływa na wartość organizacji. Dyrektywa unijna dotycząca raportowania danych niefinansowych we wskazanej grupie przedsiębiorstw stanowi początek szeroko zakrojonych prac nad raportowaniem o kapitale intelektualnym.

\section{Literatura}

Barney J.B., 1991, Firms resources and sustained competitive advantage, Journal of Management, vol. 1, s. 99-120.

Bontis N., Fitzenz J., 2002, Intellectual capital ROI: a casual map of human capital antecedens and consequents, Journal of Intellectual Capital, vol. 3, no. 3, s. 223-247.

Cuganesan S., Petty R., 2010, Intellectual capital measurement and reporting: issues and challenges for multinational organizations, [w:] Strategic Intellectual Capital Management in Multinational Organizations Sustainability and Successful Implications, ed. K.J. O’Sullivan, Business Science Reference, NY, s. 81.

Dominiak P., Mercik J., Szymańska A., 2012, Ocena metod pomiaru kapitału intelektualnego przedsiębiorstw, Zeszyty Naukowe Uniwersytetu Szczecińskiego, Finanse, Rynki Finansowe, Ubezpieczenia, nr 91, s. 683-693.

Dudycz T., 2005, Zarządzanie wartościa przedsiębiorstwa, PWE, Warszawa.

Edvinsson L., 2002, [w:] EC examines reporting rules for intangibles, ed. E. Truth, The Knowledge Management Forum. Henley Management College, February, www.kmmag. co.uk (10.01.2017).

Edvinsson L., Malone M.S., 2001, Kapitat intelektualny, PWN, Warszawa.

Fijałkowska J., 2016a, Sprawozdawczość kapitału intelektualnego wyzwaniem rachunkowości, www. konkurencyjnosc.gpv.pl. (12.01. 2017).

Fijałkowska J., 2016b, Raportowanie informacji niefinansowych zgodnie z nowa dyrektywa UE 2014/95/UE jako wyzwanie dla przedsiębiorstw, Prace Naukowe Uniwersytetu Ekonomicznego we Wrocławiu, nr 436, s. 115-122.

Guzińska-Błońska A., 2016, Zintegrowane raportowanie - nowe regulacje stawiaja wyzwania $i$ szanse, www.roedl.com (10.02.2016).

Kasiewicz S., Rogowski W., Kicińska M. (red.), 2006, Kapitał intelektualny, Oficyna Wydawnicza, Kraków.

Kunasz M., 2005, Próba wyceny kapitału intelektualnego przedsiębiorstw notowanych na GPWw Warszawie, [w:] Konkurencyjność rynku pracy i jego produktów, red. D. Kopycińska, Wydawnictwo Uniwersytetu Szczecińskiego, Szczecin, s. 156.

Lipka A., 2007, Nowoczesne metody wyceny kapitału ludzkiego, Przegląd Organizacji, nr 9, s. 20-23.

Luthy D.H., 2001, Intellectual capital and its measurement, www3.bus.osaka-cu.ac.jp/apira98/archives/pdfs/25.pdf (4.03.2017).

Mroziewski M., 2008, Kapitat intelektualny współczesnego przedsiębiorstwa: koncepcje, metody wartościowania i warunki jego rozwoju, Difin, Warszawa.

Ministerstwo Finansów, 2016, http:// www.mf.gov.pl/c/document_library (10.02.2017).

Rogowski W., 2006, Kapitat intelektualny jako generator nowych czynników konkurencyjności, [w:] Kapitat intelektualny, red. S. Kasiewicz, W. Rogowski, M. Kicińska, Oficyna Wydawnicza, Kraków.

Skrzypek A., 2016, Teoria interesariuszy i zarzadzanie relacjami z interesariuszami, [w:] Wołczek P., Skrzypek A., Szymański R., Strategiczny CSR, Texter, Warszawa, s. 39-80. 
Sopińska A., 2005, Istota kapitatu intelektualnego przedsiębiorstwa, [w:] Pomiar kapitatu intelektualnego przedsiębiorstwa, red. P. Wachowiak, SGH, Warszawa.

Sopińska A., 2010, Wiedza jako strategiczny zasób przedsiębiorstwa. Analiza i pomiar kapitału intelektualnego przedsiębiorstwa, Oficyna Wydawnicza SGH, Warszawa.

Sveiby K.E., 2001, Methods of Measuring Intangible Assete, htpp://www.sveiby. com/articles/Intangible-Methods.htm (4.03.2017).

Szara K., Pierścionek A., 2007, Kapitat intelektualny jako obszar konkurencji przedsiębiorstw, Nierówności Społeczne a Wzrost Gospodarczy, Gospodarka oparta na wiedzy, red. M.G. Woźniak, Uniwersytet Rzeszowski, Rzeszów.

Urbanek G., 2008, Wycena aktywów niematerialnych przedsiębiorstwa, PWE, Warszawa. 